\title{
IDW '11
}

IDWは，電子情報ディスプレイ技術分野において，最新の研究開発成果を発表・議論することを目的と して，ITEとSIDの主催で開催される国際会議である。18回目となる2011年の会議は12月7日〜9日の3日間 の日程で名古屋国際会議場にて行われた。本技術分野の研究開発はまだまだ非常に活発で，新規技術の進 化発展に対しても，IDWは今後も貢献し続けるであろう。

キーワード：酸化物エレクトロニクス，ディスプレイ国際ワークショップ (IDW)，電子情報ディスプレイ，映像情報メディア学会 (ITE), The Society for Information Display (SID)

\section{1.まえがき}

International Display Workshops (IDW) は, 電子産業の 要である電子情報ディスプレイ技術分野において，最新の 研究開発成果を発表・議論することを目的として, 映像情 報メディア学会 (ITE) とSociety for Information Display (SID) の主催で開催される国際会議である.

ディスプレイを取り巻く環境は，近年大幅に変化してき ている．テレビの市場は，薄型大画面高精細の液晶ディス プレイ (LCD) やプラズマディスプレイ (PDP) に世界的に も置き換わり，デスクトップパソコンのディスプレイは， 大型化, 高精細化, 動画対応へ, ノートパソコンは多品種 化，高精細化へと進んでいる。タブレット端末が生み出さ れてタッチパネル入力が用いられ，携帯電話はスマートフ オンへと進化して，インターネットやアプリ対応など多く の機能を搭載し, 画面サイズの大型化および高精細化が求 められている。このように, 使用されるディスプレイデバ イスは多種多様化してきている。

それに伴い，本国際会議IDWでも，ディスプレイデバイ スの研究開発や応用のみならず，その基礎科学，物性，人 間工学，環境工学など，幅広い分野の研究者が携わるよう になってきている，日本は世界に先駆けて，ディスプレイ 産業を育ててきたが，IDWは，次の世代の技術を育て，日 本のみならずディスプレイ産業に携わる世界中の研究者, 技術者の育成を目的として，最新の研究成果の発表や討論， 情報交換の場を提供している。

IDWは，1994年に第1回が開催されて以来，毎年日本各 地で開催されている。18回目となる2011年の会議は 12 月 7 日〜9日の3日間の日程で名古屋国際会議場にて行われた. 正式名称は第18回ディスプレイ国際ワークショップ (The

†龍谷大学 理工学部 電子情報学科

"IDW '11" by Mutsumi Kimura (Department of Electronics and Informatics, Ryukoku University, Shiga) 18th International Display Workshops)であり, IDW '11と 略される．本報告では，その開催状況について紹介する.

\section{2. 会議の概要}

IDW '11では，初日の午前のプレナリーセッションのの ち，3日間にわたり15のワークショップと二つのトピカル セッションによるパラレルセッションのオーラルセッショ ンとポスタセッションが開催された.

\section{表1 分野別発表論文数}

\begin{tabular}{|c|l|c|c|c|c|}
\hline \multicolumn{2}{|c|}{ 略 } & ワークショップ/トピカルセッション 招 待 & オーラル & ポスタ & 合 計 \\
\hline \hline Keynote Addresses/Invited Addresses & 4 & - & - & 4 \\
\hline LCT & LC Science and Technologies & 2 & 17 & 41 & 60 \\
\hline AMD & Active Matrix Displays & 9 & 19 & 32 & 60 \\
\hline FMC & $\begin{array}{l}\text { FPD Manufacturing, Materials and } \\
\text { Components }\end{array}$ & 7 & 15 & 14 & 36 \\
\hline PDP & Plasma Displays & 4 & 7 & 5 & 16 \\
\hline PH & EL Displays and Phosphors & 4 & 3 & 15 & 22 \\
\hline FED & Field Emission Display and CRT & 4 & 10 & - & 14 \\
\hline OLED & $\begin{array}{l}\text { OLED Displays and Related } \\
\text { Technologies }\end{array}$ & 5 & 6 & 22 & 33 \\
\hline 3D & $\begin{array}{l}3 \text { D/Hyper-Realistic Displays and } \\
\text { Systems }\end{array}$ & 7 & 20 & 14 & 41 \\
\hline VHF & Applied Vision and Human Factors & 7 & 17 & 13 & 37 \\
\hline PRJ & $\begin{array}{l}\text { Projection and Large-Area Displays } \\
\text { and their Components }\end{array}$ & 4 & 10 & 4 & 18 \\
\hline EP & Electronic Paper & 7 & 12 & 13 & 32 \\
\hline MEET & $\begin{array}{l}\text { MEMS and Emerging Technologies } \\
\text { for Future Displays and Devices }\end{array}$ & 10 & 13 & - & 23 \\
\hline DES & Display Electronic Systems & 8 & 3 & 5 & 16 \\
\hline FLX & Flexible Displays & 7 & 16 & 8 & 31 \\
\hline INP & Touch Panels and Input Technologies & 7 & 7 & 6 & 20 \\
\hline LIT & Lighting Technologies & 7 & 5 & 24 & 36 \\
\hline AUTO & Automotive Displays & 7 & 2 & 11 & 20 \\
\hline 合計 & & 110 & 182 & 227 & 519 \\
\hline
\end{tabular}

映像情報メディア学会誌 Vol. 66, No. 4, pp. 272〜274（2012） 


表2 国別参加者数
\begin{tabular}{|l|r|r|}
\hline \multicolumn{1}{|c|}{ 国 } & 参加者 & \multicolumn{1}{c|}{$\%$} \\
\hline \hline 日本 & 884 & 65.3 \\
\hline 韓国 & 216 & 16.0 \\
\hline 台湾 & 115 & 8.5 \\
\hline 中国 & 48 & 3.5 \\
\hline アメリカ & 35 & 2.6 \\
\hline ドイツ & 16 & 1.2 \\
\hline イギリス & 11 & 0.81 \\
\hline ベルギー & 6 & 0.44 \\
\hline フランス & 5 & 0.37 \\
\hline オランダ & 4 & 0.30 \\
\hline オーストラリア & 3 & 0.22 \\
\hline シンガポール & 2 & 0.15 \\
\hline スイス & 2 & 0.15 \\
\hline スウェーデン & 2 & 0.15 \\
\hline ポルトガル & 2 & 0.15 \\
\hline タイ & 1 & 0.07 \\
\hline ニュージーランド & 1 & 0.07 \\
\hline ポーランド & 1 & 0.07 \\
\hline 合 計 & 1,354 & 100 \\
\hline
\end{tabular}

プレナリーセッションでは, オープニングリマークとし て, 組織委員長の茨木伸樹氏, SID会長のMunisamy Anandan氏, 当会会長の内田龍男教授, プログラム委員長 の筆者が開会挨拶をした。キーノートアドレスとして，東 芝の神竹孝至氏が「Technological Strategy for Picture Quality of Future Displays」, LG ElectronicsのKwangYeol Choi氏が「Current Status and Future Trend of Information Display」と題して講演した. インバイテッド アドレスとして, Oregon State UniversityのJohn F. Wager教授が「Oxide Electronics for Display Backplanes」, 東北大学の末光眞希教授が「Graphene in Electronics: Current Status and Future Outlook」と題して講演した. 講演の分野もアカデミックからビジネスまでわたり, 海外 国内のバランスもよく, 内容も興味深く, たいへん好評で あった。

ワークショップでは, IDW '10では話題のテーマを横断的 に取り扱う位置付けとして, トピカルセッションであった Touch Panels and Input Technologies (INP) が, 継続的に育 成すべき技術分野としてワークショップに移行されている. また，IDW '10より設けられたLighting Technologies (LIT) に加えて, 会場の名古屋が自動車産業の中心であることを 考慮して, Automotive Displays (AUTO) が単年度のトピカ ルセッションとして設けられている.

オーラルセッションでは，それぞれのワークショップ, トピカルセッション，あるいは複数の分野にまたがるジョ イントセッションで, 招待講演, 通常講演, Late Newsな ど，500件を超える多数の講演が行われた。パラレルセッ ションの8講演会場のなかには, 満員や立見がでるほどの

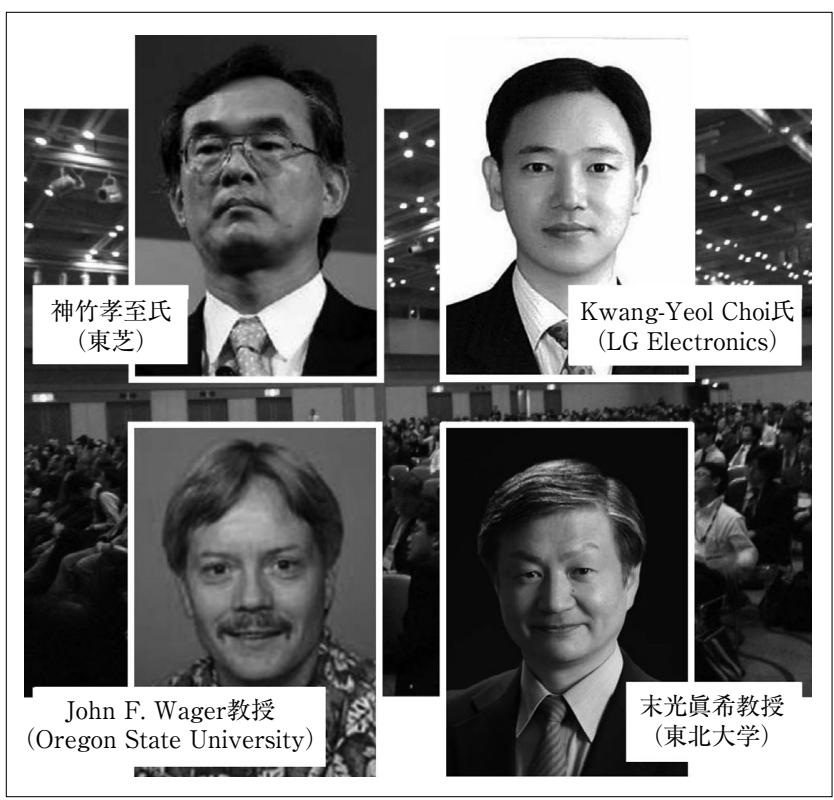

図1 キーノートアドレスとインバイテッドアドレス

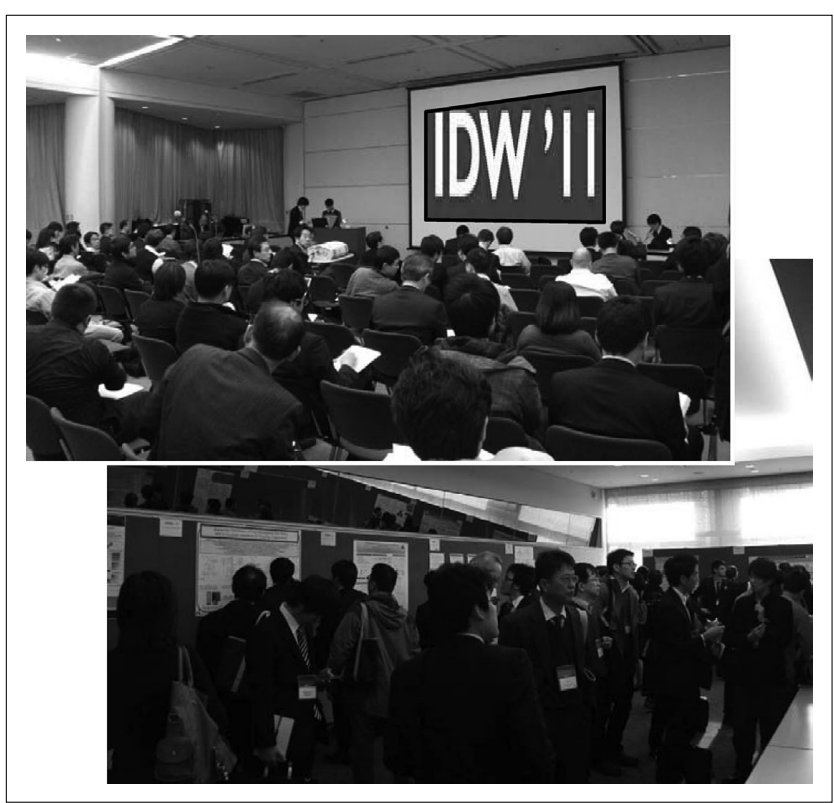

図2 オーラルセッションとポスタセッション

ところもあり，興味深い講演に活発な質疑応答があいまっ て, 発表者にとっても聴講者にとっても, 有意義な内容と なったと思われる。

ポスタセッションも200件を超え, 多くの聴講者が集ま り，たいへん活発な議論が行われた。しばしばポス夕非掲 示や発表者不在が問題となっているが, IDWでは，ポスタ 前での説明を義務づけたコアタイム制の導入や, 発表者チ エックの巡回などに取組み，着実に成果を上げつつある. 
その結果，熱気あふれるポスタセッションは, IDWの一つ の特長になりつつある. また, Electric Paper (EP)のワー クショップでは, IDWでは初の試みとしてショートプレゼ ンテーション (ポスタ講演者中の事前希望者による各5分間 ずつの質疑なし口頭講演）を行い，好評を得たＥPワーク ショップでは次回以降も継続予定であるが，今後ほかのワ ークショップへ導入するかどうかを検討したい.

展示では, 企業展示と大学・研究機関展示が行われ, 単 なる商用展示ではないアカデミックな雲囲気での展示とな った。

優れた研究発表には, “Best Paper Award” と“Outstanding Poster Paper Award”が授与された.また，大学展示には， 若手研究者育成を目的とした助成を本年度も継続した.

講演件数や参加者数については, 東日本大震災や特にディ スプレイ産業をとりまく経済状況による悪影響が懸念され たが，その影響は最小限にとどまった．講演件数と参加者 数は, 韓国や台湾をはじめ海外からは減少しているが, 講 演件数は日本からはむしろ微増しており, ディスプレイ産 業での日本の底力あるいは意地といったものが感じられる.

\section{3.むすび}

電子情報デイスプレイの研究開発はまだまだ非常に活発
で，特にアジアはディスプレイ産業の中心であり, IDWの 果たすべき役割はたいへん大きい. 新規技術の開発も盛ん で，フレキシブル技術，3D技術，有機ELディスプレイや 電子ペーパなどの分野が大きな注目を集めている．特に近 年は, 日本発の酸化物半導体薄膜トランジスタの研究開発 に各国のさまざまな機関が多くのリソースを投入し, IDW '11でも刮目すべき講演が多くあった。これらの新規技術の 進化発展に対しても, IDWは今後も貢献し続けるであろう.

最後に, 参加者, 講演者, ITE, SID, 協賛組織, 賛助金 拠出機関の皆様，科学研究費補助金 (研究成果公開促進費), 旭硝子財団, 会議運営に携わった各委員の皆様に感謝いた します。

なお, 次回のIDW '12は, Asia Displayと共催で, 2012年 12月4日〜7日の 4 日間の日程で国立京都国際会館にて開催 される予定であり, 各位の積極的なご参加とご支援をお願 いいたします。

(2012年2月9日受付)

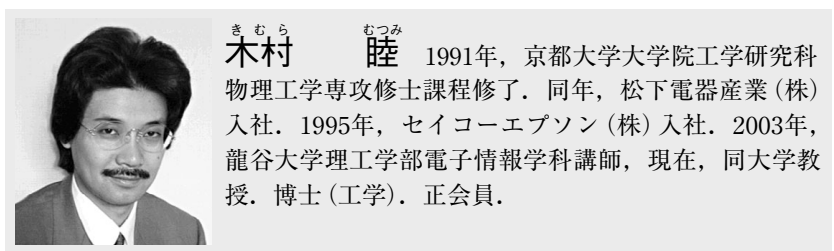

